\title{
Designing of a Traffic Signaling System at T-Intersection
}

\author{
Ramesh Surisetty*, Soma N Sekhar** \\ *(Assistant Professor, Department of Civil Engineering, Coastal Institute of Technology \& Management, \\ Vizianagaram District-AP India, Email: s.ramesh@citm.ac.in) \\ ** (Graduation Student, Department of Civil Engineering, Coastal Institute of Technology \& Management, \\ Vizianagaram District-Email: somasekhar.n1996@gmail.com)
}

\begin{abstract}
The traffic signal design of the intersection has a direct control on its safety and operation from a design and user-ability point of view. We identified Kothavalasa T-Intersection has been arise problems like road accidents, conflicts and congestions. Design elements that are particularly important include the number of lanes provided on each approach and for each movement. These problems can solve by providing an efficient traffic signal control at the intersection for continuous movement of vehicles through the intersection. According to traffic signal, most traffic signal timing plans are designed to minimize vehicle delay based on the volumes seen in the past, not the present. Traffic count studies are to be made to determine the number, movement and classification of vehicles at an intersection. Signal timing is most important which is used to decide green time of the traffic light shall be provided at an intersection and how long the pedestrian walk signal should be provided. By using Highway Capacity Manual (HCM) intersection saturation for identifying periods of time when cycle length could be substantially short. These data is used identify normal flow of the roadway; determine the influence of heavy vehicles or pedestrians on vehicular traffic volume. Webster's minimum delay cycle length equation overestimates the optimal cycle length compared to the results based on the HCM 2000 method. This is due to the restructuring of the HCM 2000 delay equation as compared to the original Webster's delay calculation.

Keywords - T-Intersection, Traffic Studies, Saturation Flow, PCU, Traffic Control, Traffic Signal
\end{abstract}

\section{INTRODUCTION}

Traffic engineering is a branch of transportation engineering that uses engineering techniques to achieve the safe and efficient movement of people and goods. It focuses mainly on research and construction of the motionless transportation necessary for this movement, such as roads, railway tracks, bridges, traffic signs and traffic lights. Traffic engineering is also defined as phase of engineering which deals with planning \& geometric design of streets, highways, abutting lands $\&$ with traffic operation thereon, as there use is related to the safe, convenient \& economic transportation of persons \& goods. Traffic engineering is a science of measuring traffic \& travel, study of the basic laws relating to traffic flow, generation \& application of this knowledge to the professional practice of planning.

Traffic signal is a usually used traffic operation manage system at urban roadway intersections. The capacity of urban road network mainly depends on the capacity of the traffic signals. Traffic Signals, also known as traffic lights, traffic lamps, signal lights, stop lights, and traffic control signals, are signaling devices located at road intersections, pedestrian crossings, and other locations to control conflicting flows of traffic. Traffic signals are an important element of traffic control devices. The installation of traffic signals has a central role in calculating traffic hazards at the intersection. An intersection is the crucial point of conflicts and congestion in the road network. Transportation is one of the critical components of the line of work from its early days. As we see, the building of roads, bridges, pipelines, tunnels, canals, railroads, ports, and harbors has shaped the profession. Civil engineering is involved in developing, building, and operating transit facilities, including street railways and underground systems and so on.

Kothavalasa Junction (T-Intersection) is one of the mostly important Major District Road (MDR) which connects to the areas of Vizianagaram, Visakhapatnam and Araku. We observed particularly this study area facing the problems like road jams and the problems like congestions, roadside vehicles and infrastructures as the number of road users are increasing quickly. They are needed to be sort out and this is impossible by traffic lights which works on predefined programs as an alternative real time data .In adding to this, it also provides access to many educational institutes, shopping centers, restaurants, corporate offices, grain market etc.

Due to the above constraints, its reflection for research work has done so far. Finally at the study area are required to provide a Traffic Signal to enable the efficient traffic control of traffic and also the faster clearing off the traffic from the 
intersection, designing \& operating traffic system to achieve safe \& efficient movement of persons \& goods. Instead of building additional infrastructure, dynamic elements are also introduced into road traffic management. These use sensors to measure traffic flows and automatic, interrelated guidance systems to manage traffic, especially in peak hours.

\subsection{SCOPE AND OBJECTIVES}

The proposed research work aims at analyze the characteristics of the mixed traffic flow to identify proper conjectural distributions for various traffic variables influencing the traffic stream characteristics, and study of the flow characteristics and vehicular interactions. The detailed objectives of the research work are as follows:

1. To identify the traffic conflicts in major \& minor streams in a particular intersection/junction.

2. To estimate the basic traffic stream parameters for the selected road.

3. To estimate the condition of study road.

4. Reduce the frequency of accidents and delays.

5. To evaluate the condition of study road.

6. To better categorize and orderly traffic movement.

7. To design and provide the signal timings at "Kothavlasa T-Intersection".

\subsection{STUDY AREA}

The major traffic conflicts occur are identified at TIntersection is:

$>$ Kothavalasa T-Intersection/Junction

\section{DATA COLLECTION}

Traffic studies or surveys are carried out to observe the traffic individuality. These studies help in deciding the geometric design features and control for safe and capable traffic movement. The various traffic studies generally carried out are:

- Traffic study

- Traffic flow characteristics

- Traffic capacity study

- Home interview study

- Pedestrian study

- Accident study

\section{METHODOLOGY}

The signal design procedure involves few important steps are:

(1) Three Phase design

(2) Determining of amber time and clearance time

(3) Determined optimum cycle length

(4) Apportioning of green time

(5) The presentation estimate of the above design.

$>$ The main objective of three phase design is to split the conflicting movements in an intersection into different phases, so that movements in a phase should have no conflicts.
If all the movements are to be separated with no conflicts, then a large number of phases are required.

$>$ To show various phase plan options, consider a four legged intersection with during traffic and right turns. Left turn is ignored.

\section{Webster's Method}

It is a critical approach of determining the optimum signal cycle time $\mathrm{C}_{0}$ corresponding to minimum delay to all the vehicles at the approach roads of the intersection.

$$
\mathrm{Co}=\frac{1.5 \mathrm{~L}+5}{1-\mathrm{Y}}
$$

Where,

$\mathrm{L}=$ Total lost time per cycle $\mathrm{sec}=2 \mathrm{n}+\mathrm{R}$

$\mathrm{n}=$ is the number of phases

$\mathrm{R}=$ all-red time or red-amber time;

$\mathrm{Y}=\mathrm{y}_{1}+\mathrm{y}_{2}$

$\mathrm{y}_{1}=\mathrm{q}_{1} / \mathrm{s}_{1}$ and $\mathrm{y}_{2}=\mathrm{q}_{2} / \mathrm{s}_{2}$

$\mathrm{G}_{1}=\mathrm{y}_{1} / \mathrm{Y}(\mathrm{Co}-\mathrm{L}), \mathrm{G}_{2}=\mathrm{y}_{2} / \mathrm{Y}(\mathrm{Co}-\mathrm{L})$

The field work consists of determining the following set of values on each approach road near the intersection:

- The normal flow " $q$ " on each approach during the design hour.

- The saturation flow ,S per unit time

The normal flow values $\mathrm{q} 1$ and $\mathrm{q} 2$ on road 1 and road 2 are determined from field studies conducted during the design hours or the traffic during peak 15 minute's period. The saturation flow of vehicles is determined from careful field studies by noting the number of vehicles in the stream of compact flow during the green phases and the corresponding intervals precisely.

Based on the selected values of normal flow, the ratio $\mathrm{y} 1=\mathrm{q} 1 / \mathrm{S} 1$ and $\mathrm{y} 2=\mathrm{q} 2 / \mathrm{S} 2$ are determined on the approach roads 1 and 2 .In the case of mixed traffic,it is necessary to convert the different vehicle classes in terms of suitable of PCU values at signalized intersection; in case these are not available the may be determined separately.

The normal flow of the traffic on the approach roads may also be determined by conducting field's studies during off-peak hours to design different sets of signal timings during other periods of the day also, as required so as to provide different signal settings 


\section{FIGURES AND TABLES}

1) Table 1 shows the Maximum No. of Vehicles and Maximum Capacity Time in the study area for 1st and 2nd hours in Morning Session at Kothavalasa Junction.

2) Table 2 shows the Maximum No. of Vehicles and Maximum Capacity Time in the study area for 1 st and 2 nd hour

3) Table 5 and 6 shows the maximum No. of Vehicles and Maximum Capacity Time in the study area for 1 st and 2nd hour at Gnanapuram Junction.

4) Figures 1, 4, 7, 9, 12, 14 show the graphs for Maximum No. of Vehicles in the study area of 1 st and 2 nd hour.

5) Figures 3, 5, 8, 10, 13, 15 show the graphs for maximum Capacity Time (Min) in the study area of 1 st and 2 nd hour.

Table-1: Hourly Variations of Traffic in Morning Peak Hours at Kothavalasa T-Intersection

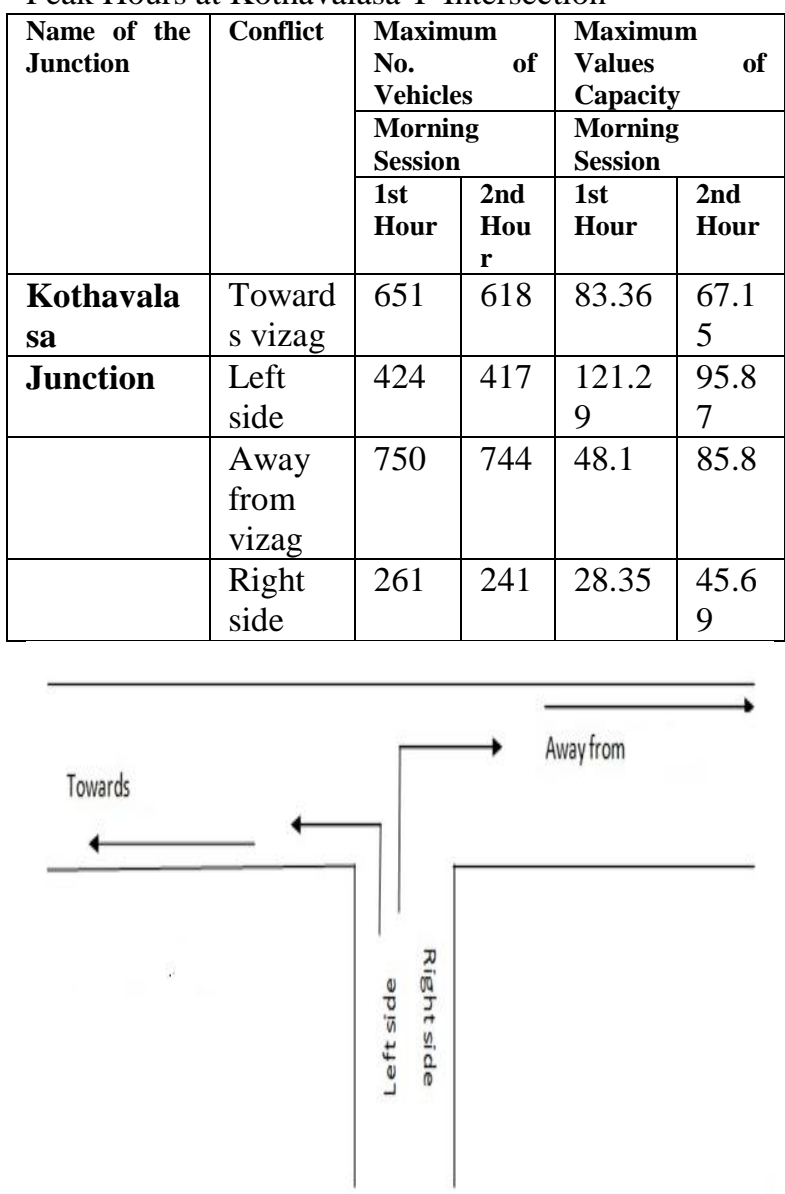

Kothavalasa T-Intersection
No.of vechicles in peak time in 1 st hour

- No.ofvechicles in peak time in 2nd hour

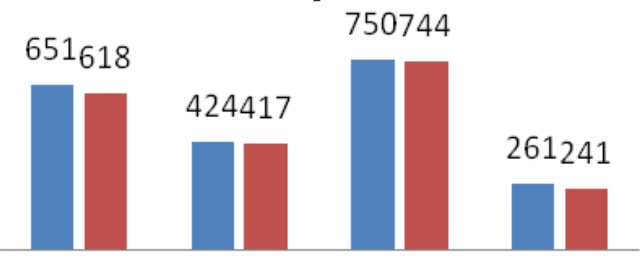

Towards Left side Away from Right side vizag vizag

Fig-1: No. of Vehicles in Evening Peak Hours

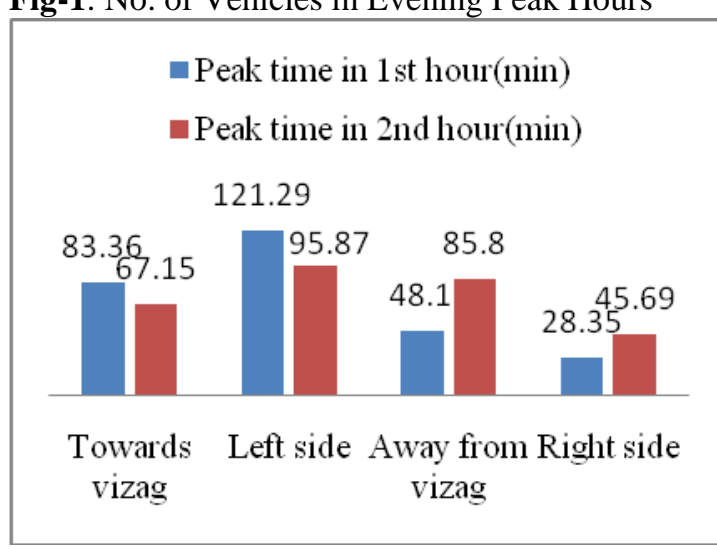
(Min)

Fig-2: Hourly Variations of Traffic Time

\begin{tabular}{|l|l|l|l|l|l|}
\hline \multirow{2}{*}{$\begin{array}{l}\text { Name of the } \\
\text { Junction }\end{array}$} & Conflict & \multicolumn{2}{|l|}{$\begin{array}{l}\text { Maximum } \\
\text { No. } \\
\text { Vehicles }\end{array}$} & \multicolumn{2}{l|}{$\begin{array}{l}\text { Maximum } \\
\text { Values } \\
\text { Capacity }\end{array}$} \\
\cline { 3 - 6 } & & $\begin{array}{l}\text { Evening } \\
\text { Session }\end{array}$ & \multicolumn{2}{|l|}{$\begin{array}{l}\text { Evening } \\
\text { Session }\end{array}$} \\
\cline { 3 - 6 } & & $\begin{array}{l}\text { 1st } \\
\text { Hour }\end{array}$ & $\begin{array}{l}\text { 2nd } \\
\text { Hour }\end{array}$ & $\begin{array}{l}\text { 1st } \\
\text { Hour }\end{array}$ & $\begin{array}{l}\text { 2nd } \\
\text { Hour }\end{array}$ \\
\hline Kothavalasa & $\begin{array}{l}\text { Towards } \\
\text { vizag }\end{array}$ & 1178 & 1149 & 231.88 & 135.88 \\
\hline Junction & $\begin{array}{l}\text { Left } \\
\text { side }\end{array}$ & 551 & 516 & 172.26 & 137.21 \\
\hline & $\begin{array}{l}\text { Away } \\
\text { from } \\
\text { vizag }\end{array}$ & 943 & 898 & 71.07 & 109.69 \\
\hline & $\begin{array}{l}\text { Right } \\
\text { side }\end{array}$ & 218 & 202 & 22.08 & 36.48 \\
\hline
\end{tabular}

Table-2: Hourly Variations of Traffic in Morning Peak Hours at Kothavalasa T-Intersection

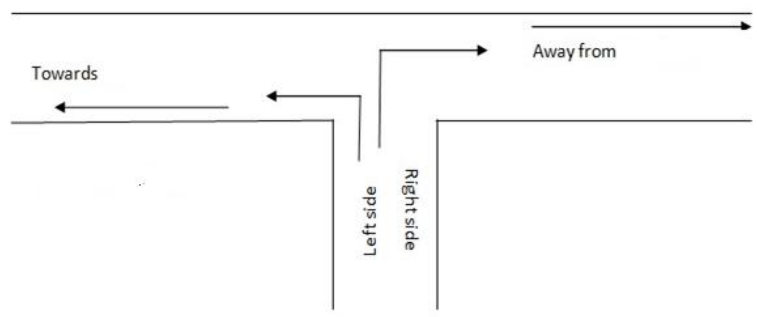

Fig-3: No. of Vehicles in Evening Peak Hours 


\section{Calculations}

- No. of vechicles in peak time in 1st hour

no. of vechicles in peak time in 2nd hour

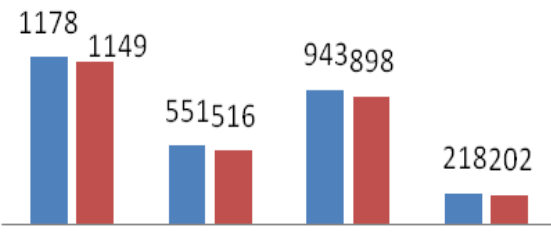

Towards Left side Away from Right side vizag vizag

Fig-4: Hourly Variations of Traffic Time (Min)

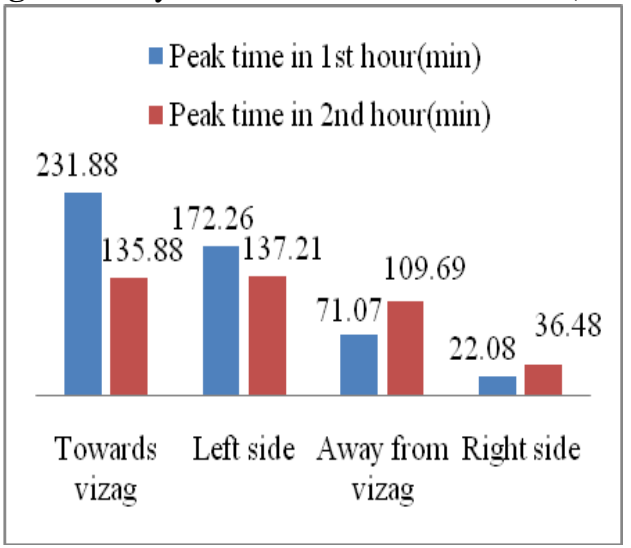

Table-3 Comparison of the peak hour Variations at Kothavalasa T-Intersection

\begin{tabular}{|c|c|c|c|c|c|}
\hline \multirow[t]{3}{*}{$\begin{array}{l}\text { Name of the } \\
\text { Junction }\end{array}$} & \multirow[t]{3}{*}{ Conflict } & \multicolumn{2}{|c|}{$\begin{array}{l}\text { Maximum } \\
\text { No. of } \\
\text { Vehicles }\end{array}$} & \multicolumn{2}{|c|}{$\begin{array}{l}\text { Maximum } \\
\text { Values } \\
\text { Capacity }\end{array}$} \\
\hline & & \multicolumn{2}{|c|}{$\begin{array}{l}\text { Morning } \\
\text { Session }\end{array}$} & \multicolumn{2}{|c|}{$\begin{array}{l}\text { Morning } \\
\text { Session }\end{array}$} \\
\hline & & $\begin{array}{l}\text { 1st } \\
\text { Hour }\end{array}$ & $\begin{array}{l}\text { 2nd } \\
\text { Hour }\end{array}$ & $\begin{array}{l}\text { 1st } \\
\text { Hour }\end{array}$ & $\begin{array}{l}\text { 2nd } \\
\text { Hour }\end{array}$ \\
\hline Kothavalasa & $\begin{array}{l}\text { Towards } \\
\text { vizag }\end{array}$ & 651 & 1178 & 83.36 & 231.88 \\
\hline \multirow[t]{3}{*}{$\begin{array}{l}\text { T- } \\
\text { Intersection }\end{array}$} & $\begin{array}{l}\text { Left } \\
\text { side }\end{array}$ & 424 & 551 & 121.29 & 172.26 \\
\hline & $\begin{array}{l}\text { Away } \\
\text { from } \\
\text { vizag }\end{array}$ & 750 & 943 & 48.10 & 71.07 \\
\hline & $\begin{array}{l}\text { Right } \\
\text { side }\end{array}$ & 261 & 218 & 28.35 & 22.08 \\
\hline
\end{tabular}

\section{Hourly Variations}

- Towards Vizag = Left side ॥ Away from Vizag | Right side

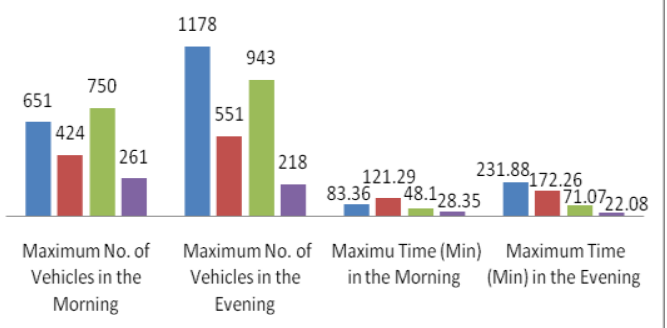

Fig-5: Comparision of Maximun No. of Vehicles taking Maximum time
Normal Flows,

$$
\begin{aligned}
& \mathrm{Y}_{1=\underline{q}_{1}=61.19} \\
& \mathrm{Y}_{2=\underline{\mathrm{q}_{2}}}{ }_{\mathrm{q}_{1}}^{\mathrm{S}_{2}}=151.04 \\
& \mathrm{Y}_{3}=\underline{\mathrm{q}_{3}}=\underline{\mathrm{q}_{2}}=489.54 \\
& \mathrm{~S}_{3} \\
& \mathrm{Y}_{4=\underline{\mathrm{q}}_{4}}=\quad 343.59 \\
& \mathrm{~S}_{4} \\
& \mathrm{Y}_{5}=\underline{\mathrm{q}}_{\underline{5}}=\quad 324.92 \\
& \mathrm{~S}_{5} \\
& \mathrm{Y}_{6=\underline{\mathrm{q}}_{6}}=\quad 656.41 \\
& \mathrm{~S}_{6} \\
& \mathrm{Y}_{\text {max }}=\mathrm{Y}_{1+} \mathrm{Y}_{2+} \mathrm{Y}_{3+} \mathrm{Y}_{4+} \mathrm{Y}_{5+} \mathrm{Y}_{6}=2026.6 \\
& \mathrm{C}_{\mathrm{o}}=\frac{1.5 \times 24+5}{(1-2026.6)}=0.020
\end{aligned}
$$

\section{Calculation of Green Time}

$\begin{aligned} \mathrm{G}_{1}=\frac{\mathrm{Y}_{1}}{\mathrm{Y}} & =\frac{61.19}{2026.6}(0.020-24)=0.72 \\ \mathrm{G}_{2}=\frac{\mathrm{Y}_{2}}{\mathrm{Y}} & =\frac{151.04}{2026.6}(0.020-24)=1.78 \\ \mathrm{G}_{3}=\frac{\mathrm{Y}}{\underline{Y}} & =\frac{489.54}{2026.6}(0.240-24)=5.79 \\ \mathrm{G}_{4}=\frac{\underline{Y}_{4}}{\mathrm{Y}} & =\frac{343.59}{2026.6}(0.020-24)=4.06 \\ \mathrm{G}_{5}=\frac{\mathrm{Y}}{{ }_{5}} & =\frac{324.92}{2026.6}(0.020-24)=3.84 \\ \mathrm{G}_{6}=\frac{\mathrm{Y}_{6}}{\mathrm{Y}} & =\frac{656.41}{2026.6}(0.020-24)=7.76\end{aligned}$

So, we chosen the min value of " $G$ " is

$=0.72 \times \mathrm{L} \quad$ where, $\mathrm{L}=2 \mathrm{n}+\mathrm{R}$

$=0.72 \times[2(6)+12]$

$=0.72 \times 24$

$=17.28 \mathrm{Sec}$

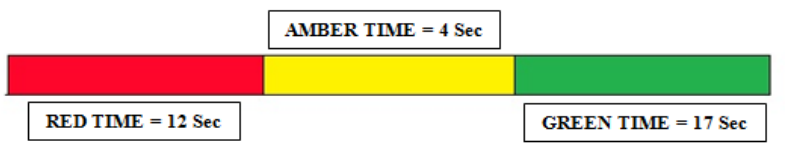

OBTAINED VALUES OF EACH SIGNAL PHASE

1) Red Time $=12 \mathrm{Sec}$

2) Amber Time $=4 \mathrm{Sec}$

3) Green Time $=17 \mathrm{Sec}$ 


\section{CONCLUSION}

Based on the calculations done on the PCU values obtained from the traffic survey.

$>$ By studying the road traffic of the city we analyzed that the major accident cause is collision of vehicles at the intersections. The collision may be rear shunt on approach to junction, right angled collision, principle right turn collisions and pedestrian collision. These collisions can be avoided if proper design of signal is done so that the main objective of the dissertation is to provide better and safe movement of traffic through signal design at the intersection. The signal is designed as per IRC guidelines so that the signal can justify the proper movement of the traffic.

$>$ By providing signals, there will be reduction in the conflicts. And also there will be an orderly movement of traffic in the cross- section for the roads from bus stop towards Viaskhapatnam, Vizianagaram and S-Kota.

\section{REFERENCES}

[1] B.Sudharshan Reddy ${ }^{1}$,N.Venkata Hussain Reddy $^{2}$ "Signal Design for T-intersection by using Webster's Method in Nandyal Town, Kurnool District of Andhra Pradesh" International Research Journal of Engineering and Technology (IRJET) Volume: 03 Issue: 04, Apr -2016.

[2] R. Vinod Kumar and Pavithra. M. "Design of Traffic Signals at closely spaced Intersectionsin Tirupati” International Journal of Advanced Research (2016), Volume 4, Issue 7, 1663-1670.

[3] Khanna S.K \& Justo C.E.G., "Highway Engineering" New Chand and Bros. Roorkee.

[4] Kadiyali L.R., "Traffic Engineering and Transport Planning" Khanna Publishers, New Delhi.

[5] IRC Code: IRC: 93-1985 "Guideline on Design and Installation of Road Traffic Signals".

[6] Ministry Of Road Transport and Highways (MORTH). 